\title{
Evaluation of the Effects of Different Inclusion Rates of Balanites aegyptiaca Seed Oil on the Growth Performance and Survival of Clarias anguillaris Fries
}

\author{
Mariama Sagne \\ University Institute of Fisheries and Aquaculture (IUPA), Cheikh Anta Diop University \\ (UCAD), 45784, Dakar, Senegal \\ Jean Fall (Corresponding Author) \\ University Institute of Fisheries and Aquaculture (IUPA), Cheikh Anta Diop University \\ (UCAD), 45784, Dakar, Senegal, E-mail: kagoshima77@yahoo.com \\ Abdoulaye Loum \\ University Institute of Fisheries and Aquaculture (IUPA), Cheikh Anta Diop University \\ (UCAD), 45784, Dakar, Senegal \\ Ibrahima Thiaw \\ University Institute of Fisheries and Aquaculture (IUPA), Cheikh Anta Diop University \\ (UCAD), 45784, Dakar, Senegal \\ Diegane Ndong \\ Direction des Ressources Animales et Halieutiques, Département de l'Agriculture, des \\ Ressources en Eau et de l'Environnement, Commission de l'UEMOA, 380 Av. Pr. Joseph \\ KI-ZERBO, 01 BP 543 Ouagadougou 01-Burkina Faso \\ Malick Diouf \\ University Institute of Fisheries and Aquaculture (IUPA), Cheikh Anta Diop University \\ (UCAD), 45784, Dakar, Senegal \\ Demba Sow
}

Ecole Supérieure Polytechnique (ESP), Université Cheikh Anta Diop de Dakar (UCAD)

Received: September 25, 2018 Accepted: October 21, 2019 Published: March 18, 2019 doi:10.5296/ast.v7i1.14519 URL: https://doi.org/10.5296/ast.v7i1.14519 


\section{Abstract}

One of the main problems facing aquaculture is the lack and high price of fishmeal and fish oil supply. The continued growth of aquaculture production cannot depend on these finite fisheries resources. It is imperative that inexpensive and readily available alternatives that do not compromise fish growth and product quality are found. It is in this specific context that this study consisting of a test of the Balanites aegyptiaca seed oil incorporated in the feed of Clarias anguillaris fries was conducted.

The experiment lasted eight (8) weeks and included five treatments of two tanks each. This corresponds to a total of 10 tanks for 150 fries with a stocking density of 15 fish per tank. Five diets supplemented with 0\% (R.0), 1\% (R.1), 2\% (R.2), 3\% (R.3) and 4\% (R.4) of the lipid source were administered twice daily for eight weeks. Growth was regularly monitored and mortalities recorded to assess the effects of each diet. The results revealed significant effects on growth performance and survival of Clarias anguillaris fries. For the average weight gain and the specific growth rate, the best result was obtained with the fish fed with diet containing 2\% Balanites aegyptiaca seed oil (R.2). The best feed conversion ratio was recorded with the diet incorporating $2 \%$ of this oil. The best survival rates $(66.67 \%$ and $70 \%)$ were observed in fries fed with diets incorporating respectively $2 \%$ and $3 \%$ of the oil. The experimental study has shown that a $2 \%$ incorporation rate is the most appropriate for the successful rearing of Clarias anguillaris fries.

Keywords: Balanites aegyptiaca seed oil, incorporation rate, Clarias anguillaris, growth, survival

\section{Introduction}

Today, the world population is more than six and a half billion of people (FAO, 2015). The fish is a vital source of protein for them, and its flesh also contains essential fatty acids including the famous omega 3. Every year 105 MT of fish, shellfish, and crustaceans or 16 kilograms per inhabitant and year are consumed. One part this production comes from fishing (60 MT) and the other part from aquaculture (45 MT) (Jammy and Fred, 2016). By 2030, the population will probably be eight billion on earth, and the fish consumption per capita will increase by $20 \mathrm{~kg} /$ person/year (Jammy and Fred, 2016). This will correspond to a total fish, shellfish, and crustaceans demand of $160 \mathrm{MT}$. The solution to fill the gap of 55MT is breeding. The choice of the species to breed is a decisive step to carry out fish farming. In this sense, Clarias anguillaris seems favorable because of its large size and rapid growth (Teugels, 1986).

Also, the growth of aquaculture around the world is reflected in the increasing use of feed compounds. Fish oil is the primary source of dietary fat in aquaculture nutrition. It is produced from small marine pelagic fish and represents a finite fishery resource ( $\mathrm{Ng}$ et al., 2003). However, due to several factors, including overfishing, which results in reduced catches and environmental changes that require tight regulation, future demand for wild fish will outpace supply (Sargent et al., 1999). The projected use of fish oil for aquaculture is expected to be about $90 \%$ of the total available by 2010 (Barlow, 2000). 


\section{$\triangle$ Macrothink}

This forecast is well verified because according to FAO (2009) more than $90 \%$ of the world's fish oil production is consumed by the aquaculture sector. Following this trend, there is an increase in the cost of fish oil, which would lead to an increase in the cost of feed for aquaculture. As a result, the demand for replacement of fish oil by cheaper and affordable lipid-rich sources is increasing (New and Wijkstrom, 2002).

Lipids are of paramount importance in the diet of fish. They allow covering the energy needs for their growth. Soybean oil, corn oil, sunflower oil, canola oil, palm oil and flaxseed oil rich in the n-6 and/or n-3 series have been reported to be good sources of lipids for tilapia (Lim et al., 2009). Studies have also shown that the incorporation of vegetable oils into fish feed, instead of fish oil, does not affect growth performance as essential fatty acid (EFA) requirements are covered (Corraze and Kaushik, 2009). It was reported that the fatty acid composition of the fish flesh reflects that of the lipids of the diets (Corraze and Kaushik, 1999). According to Basse et al. (2016 unpublished data), an oil mixture composed of Balanites aegyptiaca seed oil and Adansonia digitata seed oil gives faster growth in Clarias anguillaris fry compared to fish oil.

The amount of fat to be added to a diet depends on the source of fat and the protein/energy ratio of the diet. Using isocaloric diets with variable lipid content, De Silva et al. (1985) showed protein savings in red tilapia fry (Oreochromis $s p$ ) increased with the increasing incorporation of lipids into the diet, up to a maximum of $18 \%$. In general, warm water fish require $n-6$ polyunsaturated fatty acids or a mixture of $n-3$ and $n-6$ fatty acids, while cold-water species require fatty acids from the series. n-3 (Webster and Lim, 2002). Fish do not produce n-3 fatty acids but accumulate them by consuming either microalgae or prey fish that accumulate these n-3 fatty acids, with a large amount of antioxidants in the form of iodide and selenium, from the microalgae. These antioxidants can protect fragile polyunsaturated lipids from peroxidation (Lim et al., 2009).

The oil content of Balanites seeds is similar to peanut oil, poppy or moringa. The iodine indices of Balanites seed oil are similar to those of sunflower and soybean oil. This iodine content attests the nutritional potential of this oil. Mainly, four fatty acids represent $99 \%$ of the Balanites seed oil. It contains low levels of polyunsaturated fatty acids with long chains: EPA and DHA (Baobab of flavors, 2011). Balanites aegyptiaca seed oil can be used as cooking oil or consumed as such by adding it to foods at mealtime to give them a taste very popular with consumers. Moreover, it is a regulator of arterial hypertension.

The primary objective of the present study was to evaluate the effects of different inclusion rates of Balanites aegyptiaca seed oil on the survival and growth of Clarias anguillaris fries.

\section{Material and Methods}

\subsection{Experimental Device}

The experimental test of this study took place at the University Institute of Fisheries and aquaculture (IUPA) hatchery located at the Faculty of Science and Technology (FST) of the University Cheikh Anta Diop of Dakar (UCAD), more precisely at the Department of Animal Biology. It consists of two closed recycled systems and one hatchery unit. Our experience took place in an isolated system consisting of 10 plastic tanks with a capacity of 50L each, a 


\section{Macrothink

storage tank with a capacity of $500 \mathrm{~L}$ and a $3 \mathrm{~m}^{3}$ water socking tank and five air pumps with two air stones each for the oxygenation of the rearing medium.

\subsection{Methods}

\subsubsection{Culture Conditions}

The experiment lasted eight (8) weeks and included five treatments of two tanks each. This corresponds to a total of 10 tanks for 150 fries with a stocking density of 15 fish per tank. The tanks were filled with water up to half their volume (25 liters). The tanks were covered by perforated lids to prevent excessive heating of the water. Each tank was equipped with an air stone for ventilation of the living environment.

The feed was given to the fry twice a day (morning at 7:45 am and evening at 6:45 pm) at $20 \%$ of their body weight for the first six weeks and $16 \%$ after that until the end of the experiment.

Growth control was done every two weeks. It consisted of weighing the fry of each tank to evaluate the evolution of the biomass. Immediately, the fish were returned to the tanks after weighing, cleaning and renewing the water. Total biomass was calculated per tank to adjust the daily ration.

\subsubsection{Diet Preparation}

The different ingredients used in the diet formulation were obtained locally in the markets.

The Diet formulator software was used to formulate five types of diets for a quantity of one kilogram $(1 \mathrm{~kg})$ each. The composition of each diet (R.0, R.1, R.2, R.3, and R.4) was recorded in the following Table I. These diets differ from each other in the amounts of oil and peanut shells meal was incorporated in the feed (see Table IV). The estimation of the biochemical composition was recorded in Table II.

Diets manufacturing was carried out in four main stages. First, some ingredients were treated to remove some impurities they contain. Then followed the selection and weighing of each ingredient according to the formulation shown in Table I. Finally, all ingredients were manually homogenized, $30 \%$ water and Balanites seed oil added. The dough obtained was passed through an extruder to get filaments like spaghetti. The filaments were dried under the sun for two days. The diets obtained were stored in plastic bins with lids. 
Table I. Composition of the different diets

Ingredients

Treatments

\begin{tabular}{|c|c|c|c|c|c|}
\hline & R.0 & R.1 & R.2 & R.3 & R.4 \\
\hline Moringa leaf meal (g) & 300 & 300 & 300 & 300 & 300 \\
\hline Peanut cake meal (g) & 300 & 300 & 300 & 300 & 300 \\
\hline Fishmeal (g) & 200 & 200 & 200 & 200 & 200 \\
\hline Tomato waste meal (g) & 80 & 80 & 80 & 80 & 80 \\
\hline Vitamines mix (g) ${ }^{a}$ & 10 & 10 & 10 & 10 & 10 \\
\hline Minerals mix $(g)^{b}$ & 10 & 10 & 10 & 10 & 10 \\
\hline Bentonite (Binder) (g) & 10 & 10 & 10 & 10 & 10 \\
\hline Balanites aegyptiaca seed oil (g) & $\mathbf{0}$ & 10 & 20 & 30 & 40 \\
\hline Peanut shell meal (g) & 90 & 80 & 70 & 60 & 50 \\
\hline
\end{tabular}

Table II. Estimation of the biochemical composition of the diets

\begin{tabular}{lccccc}
\hline & R.0 & R.1 & R.2 & R.3 & R.4 \\
\hline DM (\%) & 74.42 & 75.42 & 76.42 & 77.42 & 78.42 \\
Ash (\%) & 4.51 & 4.51 & 4.51 & 4.51 & 4.51 \\
Protein (\%) & 35.99 & 35.87 & 35.74 & 35.62 & 35.50 \\
Lipid (\%) & $\mathbf{8 . 0 4}$ & $\mathbf{9 . 0 2}$ & $\mathbf{1 0 . 0 1}$ & $\mathbf{1 1 . 0 0}$ & $\mathbf{1 1 . 9 9}$ \\
Fiber (\%) & 3.93 & 3.93 & 3.93 & 3.93 & 3.93 \\
Ca (\%) & 0.10 & 0.10 & 0.10 & 0.10 & 0.10 \\
P (\%) & 0.17 & 0.17 & 0.17 & 0.17 & 0.17 \\
\hline
\end{tabular}

(a: vitamines, b: minerals) 
$\mathrm{a}=$ vit A $250000 \mathrm{UI}$; vit D3 250000UI; vit E 5000mg; vit B1 100mg; vit B2 400mg; vit B3(pp) 1000mg; vit B5 pantode Ca2000mg; vit B6 300mg; vit K3 1000g; vit C 5000mg; H biotin 15mg; choline 100g; anti-oxydant (BHT), crushed and calcined attapulgite qs 1000mg;

$\mathrm{b}=$ phosphorus $7 \%$; calcium $17 \%$; sodium $1,5 \%$; potassium $4,6 \%$; magnesium $7,5 \%$; manganese 738mg; zinc 3000mg; iron 4000mg; copper 750mg; iodine 5mg; cobalt 208mg; calcined and ground attapulgite qs $1000 \mathrm{~g}$; fluorine $1.5 \%$ (approximately),

\subsubsection{Water Quality Control}

Physico-chemical parameters (temperature and $\mathrm{pH}$ ), siphoning and water renewal were conducted twice a day (morning and evening) to monitor and control the water quality.

Before its use, the water was stored in the reservoir for approximately forty-eight (48) hours to be sufficiently dechlorinated.

\subsubsection{Data Processing}

\subsubsection{The Parameters of Fish Growth and Survival}

The growth parameters were described as in the following formulas:

Absolute Mean weight gain $(\mathrm{AWGa},(\mathrm{g} / \mathrm{fish}))$ = final mean body weight - initial mean body weight;

Specific growth rate $(\mathrm{SGR},(\% /$ day $))=((\mathrm{In} \mathrm{Wt}-\mathrm{In} \mathrm{Wi}) / \mathrm{T}) \times 100$, where Wt is the weight of fish at time $\mathrm{t}, \mathrm{Wi}$ is the weight of fish at time 0 , and $\mathrm{T}$ is the rearing period in days;

Feed conversion rate $(\mathrm{FCR})=$ total dry feed fed $(\mathrm{g} / \mathrm{fish}) /$ total wet weight gain $\mathrm{g} /$ fish .

Survival rate $(\%)=100 *$ (number of fish which survived/initial number of fish).

\section{Results}

\subsection{Synthesis of Physicochemical Parameters of Water}

Maximum, minimum, mean, and standard deviations of temperature and $\mathrm{pH}$ per treatment are shown in Table III. 
Table III. Maximum (Max), minimum (Min), mean and standard deviation (SD) values of temperature and $\mathrm{pH}$

\begin{tabular}{llllllllll}
\hline \multicolumn{3}{c}{ Temperature $\left({ }^{\circ} \mathrm{C}\right)$} & \multicolumn{3}{c}{ pH } \\
\hline & Max. & Min. & Mean & SD & Max. & Min. & Mean & SD \\
R.0 & 26.23 & 22.15 & 24.25 & 4.08 & 8.52 & 5.69 & 7.06 & 2.83 \\
R.1 & 26.28 & 22.15 & 24.21 & 4.13 & 8.52 & 5.69 & 7.07 & 2.83 \\
R.2 & 26.18 & 22.15 & 24.18 & 4.03 & 8.51 & 5.70 & 7.07 & 2.82 \\
R.3 & 26.23 & 22.35 & 24.36 & 3.88 & 8.52 & 5.75 & 7.08 & 2.77 \\
R.4 & 26.45 & 22.70 & 24.59 & 3.75 & 8.53 & 5.73 & 7.08 & 2.80 \\
\hline
\end{tabular}

\subsubsection{Temperature}

The values of the temperature evolved sawtooth during the experiment with an amplitude of $4.3^{\circ} \mathrm{C}$. The trend of evolution is slightly identical in all treatments. The lowest value $\left(22.15^{\circ}\right.$ C) was recorded on the first day at the R0, R1 and R2 treatments and the highest $\left(26.45^{\circ} \mathrm{C}\right)$ is observed at the fifty-third (53rd) day at the R4 level.

\subsection{2 $\mathrm{pH}$ of the Water}

Overall, the change in $\mathrm{pH}$ of the water during the experimental period is characterized by a gradual increase (especially from the second week to the end of the experiment). The $\mathrm{pH}$ values recorded during the experiment show a minimum of 5.69 and a maximum of 8.53 . This variation was found in all treatments.

\subsection{Growth, Survival and Feed Efficiency}

Data on total average weight gain (AWGa), relative mean weight gain (AWGr), specific growth rate (SGR), feed conversion ratio (FCR) and survival rate (SR) are shown in Table IV. 
Table IV. Growth performance, feed efficiency, and survival

\begin{tabular}{lccccc}
\hline & R.0 (0\%) & R.1 (1\%) & R.2 (2\%) & R.3 (3\%) & R.4 (4\%) \\
\hline IMW (g) & 0.33 & 0.33 & 0.33 & 0.33 & 0.33 \\
FMW(g) & 0.50 & 0.64 & 0.66 & 0.56 & 0.56 \\
AWGa (g) & 0.17 & 0.31 & 0.33 & 0.23 & 0.23 \\
AWGr (\%) & 51.52 & 93.94 & 98.96 & 68.77 & 69.36 \\
SGR (\%/d) & 0.74 & 1.17 & 1.22 & 0.93 & 0.94 \\
FCR & 0.69 & 0.43 & 0.33 & 0.43 & 0.73 \\
SR (\%) & 60.00 & 56.67 & 66.67 & 70.00 & 46.67 \\
\hline
\end{tabular}

\subsubsection{Growth Parameters (AWGa, AWGr, and SGR)}

Overall, the best growths (AWGa, AWGr, and SGR) were obtained with the fish fed with R2 diet (2\%) followed by the fish fed with R1 diet (1\%) compared to the results obtained for the fish fed with R0, R3, and R4 diets. The control diet is left with the lowest SGR.

The AWGa obtained after each weight control are shown in Table V.

Table V. Variations of the absolute mean weight gain (g) during the experiment

\begin{tabular}{lccccc}
\hline & W0 & W2 & W4 & W6 & W8 \\
\hline R.0 (0\%) & 0.33 & 0.36 & 0.41 & 0.45 & 0.50 \\
R.1 (1\%) & 0.33 & 0.39 & 0.44 & 0.51 & 0.64 \\
$\mathbf{R . 2 ( 2 \% )}$ & 0.33 & 0.39 & 0.48 & 0.54 & 0.66 \\
$\mathbf{R . 3 ( 3 \% )}$ & 0.33 & 0.38 & 0.47 & 0.52 & 0.56 \\
$\mathbf{R . 4 ( 4 \% )}$ & 0.33 & 0.39 & 0.45 & 0.50 & 0.56 \\
\hline
\end{tabular}

W: week; R: diet

The fry growth rate in all treatments during the first two weeks was almost the same. From the third week to the end of the experiment, the fry fed with diet containing $2 \%$ Balanistes seed oil (R.2) showed a faster growth rate (Table V), followed by those fed with the others diets. The 
control diet (R.0) gave the lowest growth rate throughout the experiment (Table V).

The best FCR was observed in the fish fed with R2 diet (0.33) followed by the fish fed with R1 (0.43) and those fed with R3 (0.43) compared to the FCR observed with the fish fed with R0 (0.69) and R4 (0.73) diets (Table V).

The survival rate varied from $46.67 \%$ to $70 \%$. The highest value (70\%) was obtained with the fish fed with R3 diet followed by those fed with R2 (66.67\%), R0 (60\%), R1 (56.67). Fish fed with diet R4 showed the lowest value (46.67\%).

\section{Discussion}

The present study reveals low SGR values (0.74\%/d (R.0), 1.17\%/d (R.1), 1.22\%/d (R.2), $0.93 \% / d$ (R.3) and 0.94\%/d (R.4)).

However, it is reported that vegetable oils enhance the growth of some freshwater species (Ng et al. 2003). According to Alava (1998), a total substitution of fish oil by coconut oil does not affect the growth performance of the golden bream (Sparus aurata). Ng et al. (2003) found that African catfish (Clarias gariepinus) showed better growth when fed with semi-purified diets containing $10 \%$ palm oil as only dietary fat compared to fish fed with Cod liver oil. OKOYE and EYO (2002) tested the effects of replacing fish oil with shea butter oil, porcelain oil, and palm oil on $C$. anguillaris fry for fifty-six (56) days. The SGR obtained with shea butter oil $(2.65 \% / \mathrm{d})$, porcelain oil $(1.79 \% / \mathrm{d})$ and palm oil $(1.54 \% / \mathrm{d})$ are all larger than the best SGR found in our study $(1.22 \% / \mathrm{d})$.

The studies conducted by Bass et al. (2016 unpublished data) who used a mixture of Balanites aegyptiaca and Adansonia digitata seed oils showed good growth of $C$. anguillaris fry. According to these authors, this good growth was due to Balanites aegyptiaca seed oil rather than Adansonia seed oil lipid source.

By these findings, one might wonder whether the small growth observed is not due to the nutritional quality of the ingredients constituting the different diets. However, we may note that the SGR obtained with the control treatment in the OKOYE and EYO (2002) studies ( $\mathrm{SGR}=1.14 \% / \mathrm{d})$ is larger than that recorded with the control diet of the present study (SGR $=0.74 \% / \mathrm{d})$. More analysis shows that the ratio between these $(r=0.74 / 1.14=0.65)$ is smaller than that between the SGR obtained with palm oil in the same authors and those of diets R.1 and R.2 of the present study ( $\mathrm{r}^{\prime}=1.17 / 1.54=0.76$ and $\mathrm{r} "=1.22 / 1.54=0.79$ ). This difference in proportionality would be in favor of an affirmation that would support the efficacy of Balanites aegyptiaca seed oil, and it is reported that a high amount of saturated fatty acid (SFA) facilitates protein-saving actions and therefore good growth of fish (Ehsan et al., 2012), supported by $\mathrm{Ng}$ et al (2008) who stated that low levels of saturated fatty acids (SFAs) result in a lack of protective action of Tor tambroides dietary lipids. According to Baobab des saveurs (2011), Balanites aegyptiaca seed oil is rich in saturated fatty acids $(27.5 \%)$.

Also, the most effective regime is the one that registers the lowest FCR value. In the present study, the best FCR is also obtained with the fish fed with R.2 diet with a value of 0.33 
compared to other treatments such as the control diet where we have a FCR of 0.69. This is in line with Corraze and Kaushik (2009) who argued that freshwater fish appreciate plant-derived lipids. Moreover, Babalola and Apata (2012) suggested that the replacement of cod liver oil with palm oil as a lipid supplement in the diet has resulted in a marked improvement in the FCR of Heterobranchus longifilis.

At the end of the experiment, the recorded survival rates (70\% (R.3), 66\% (R.2), 56\% (R.1), $60 \%$ (R.0) and $46 \%$ (R.4)), although acceptable, are lower than those of OKOYE and EYO (2002) using $100 \%$ of shea butter oil, $100 \%$ of porcelain oil, $90 \%$ of palm oil and $95 \%$ of oil in the control treatment. Most recorded mortalities occurred during the first few days after the weighing sessions so that the mortalities could be explained by the handling (catch and weighing) of the fry during the checks.

Environmental conditions constitute an essential aspect, which must be taken into account. The variations in hydrogen potential $(\mathrm{pH})$, as noted above, range from 5.69 to 8.53 during the experiment. These values are included in the optimal range for the growth of Clarias (6.5 to 9) reported by Kanangire, 2001. Moreover, catfish manage to live in poor environmental conditions (Hecht, 1996). So $\mathrm{pH}$ has certainly not been a limiting factor for growth and survival performance.

For good catfish growth, temperature values should be between 26 and $30^{\circ} \mathrm{C}$ according to (Baras and Jobling, 2002). For more than three quarters (3/4) of the duration of the test, the values of the temperature are below the lower limit of this interval. Temperature could, therefore, be a limiting factor for the expression of fry growth potential during this study.

The objective of this study, which was to determine the best rate of incorporation, is achieved. In sum, the feed formulated with a proportion of $2 \%$ of Balanites aegyptiaca seed oil (R.2) gave better growth performance resulting in the best AWGr, the largest SGR and the best FCR.

\section{Conclusion and Perspectives}

For the intensive development of world aquaculture and the scarcity of fisheries resources, the substitution of marine by-products for the feeding of farmed fish is inevitable. This is a significant challenge for the future of the sector in the world.

Since the lipid source of Balanites aegyptiaca seed oil may be a solution for the replacement of fish oil in aquaculture feeds, the present study focuses only on determining the fair highest inclusion rate. It appears that the feed incorporating $2 \%$ Balanites aegyptiaca seed oil is better adapted for the growth and survival of $C$. anguillaris fries compared to those which have $0 \%, 1 \%, 3 \%$ or $4 \%$.

It was also remarkable that the temperature was significantly low during the experimental period and thus had a negative influence on fry growth. 


\section{References}

Alava, V. R. (1998). Effect of salinity, dietary lipid source and level on growth of milk fish (Chanos chanos) fry. Aquaculture, 167, 229-236.

https://doi.org/10.1016/S0044-8486(98)00317-2

Babalola, T. O., \& Apata, D. F. (2012). Impact of palm oil and extracted fishmeal on haematological parameters, serum constituents and histology of African catfish (Heterobranchus longifilis) fingerlings. Journal of Agriculture and Rural Development in the Tropics and Subtropics 113, 1-11.

Baras, E., \& Jobling, M. (2002). Dynamics of intracohort cannibalism in cultured fish. Aquaculture Research, 33, 461-479. https://doi.org/10.1046/j.1365-2109.2002.00732.x

Barlow, S. (2000). Fishmeal and oil: Sustainable feed ingredients for aquafeeds. Global Aquacult. Advocate, 4, 85-88.

Bass, M., Fall, J., Loum, A., \& Sagne, M. (2016). Etude de l'effet de la substitution de l'huile de poisson par un mélange des huiles de Balanites aegyptiaca et d'Adansonia digitata sur la croissance et la survie des alevins de Clarias anguillaris (Linnaeus ,1758). Mémoire de fin d'études pour l'obtention du Diplôme d'agent technique. Centre National de Formation des Techniciens des Pêches et de l'Aquaculture (CNFTPA).

Corraze, G., \& Kaushik, S. (1999). Les lipides des poisons marins et d'eau douce. OCL; 6, $111-115$.

Corraze, G., \& Kaushik, S. (2009). Alimentation lipidique et remplacement des huiles de poisson par des huiles végétales en pisciculture. CahAgric; 18, 112-118.

De Silva, S. S., \& Perera, M. K. (1985). Effects of dietary protein level on growth, food conversion, and protein use in young Tilapia nilotica at four salinities. Trans. Am. Fish. Soc, 583-589. https://doi.org/10.1577/1548-8659(1985)114<584:EODPLO>2.0.CO;2

Ehsan, R., Kamarudin, M. S., Saad, C. R., \& Harmin, S. A. (2012). Effects of dietary fish oil replacement by various vegetable oils on growth performance, body composition and fatty acid profile of juvenile Malaysian mahseer, Tor tambroides. Aquaculture Nutrition, 18, 532-543. https://doi.org/10.1111/j.1365-2095.2011.00907.x

FAO. (2009). Situation mondiale de la pêche et de l'aquaculture

FAO. (2015). Situation mondiale de la pêche et de l'aquaculture

Hecht, T. (1996). An alternative life history approach to the nutrition and feeding of Siluroidei larvae and early juveniles. Aquatic Living Resources, 9(5), 121-133. https://doi.org/10.1051/alr:1996047

Jammy \& Fred, 2016. Des poissons bien élevés. C'est pas sorcier.

Janssen, J. (2016). Élevage du poisson-chat africain, Clarias lazera (Cuvier \& Val., 1840) En République. FAO - département des pêches 
Kanangire, C. K. (2001). Effet de l'alimentation des poissons avec Azolla sur l'écosystème agro piscicole au Rwanda. Dissertation présentée en vue de l'obtention du grade de Docteur en Sciences. Facultés universitaires Notre-Dame de la paix, Namur, Belgique. 220p.

Legendre, M., \& Lévêque, C. Les poissons des eaux continentales africaines. Aquaculture pp 457-470.

Lim, A., John, D. H., Ellsworth, LeDrew, Peter, J. M., \& Chris, R. (2009). The effects of ecologically determined spatial complexity on the classification accuracy of simulated coral reef images. Remote Sensing of Environment, 113, 965-978.

https://doi.org/10.1016/j.rse.2009.01.011

Médale, F. (2013). Des aliments à base de végétaux pour les poissons d'élevage INRA Prod. Anim., 26(4), 303-316,

Micha, J. C. (1975). - Synthesis of research on reproduction, stocking and production in African catfish: Clarias lazera Val. Bulletin Française de Pisciculture, 256, 77-87. https://doi.org/10.1051/kmae:1975012

New, M. B., \& Wijkström, U. N. (2002). Use of fishmeal and fish oil in aquafeeds Further thoughts on the fishmeal trap. Development Planning Service Fishery Policy and Planning Division FAO Fisheries Department.

Ng, W., Abdullah, N., \& De Silva, S. S. (2008). The dietary protein requirement of the Malaysian mahseer, Tor tambroides (bleeker), and the lack of protein-sparing action by dietary lipid. Aquaculture, 284, 201-206. https://doi.org/10.1016/j.aquaculture.2008.07.051

Ng, W., Lim, P., \& Boey, P. (2003). Dietary lipid and palm oil source affects growth, fatty acid composition and muscle $\alpha$-tocopherol concentration of African catfish, Clarias gariepinus. Aquaculture, 215, 229-243. https://doi.org/10.1016/S0044-8486(02)00067-4

Okoye, F. C., \& Eyo, A. A. (2002). The Growth and Survival of Clarias Anguillaris Fingerlings Fed on Various Lipid Sources. National Institute for Freshwater Fisheries Research, P.M.B. 6006, New Bussa, Niger State.

Paugy, D., Lévêque, C., \& Teugels, G. G. (2003). Les poissons des eaux douces et saumâtres de l'Afrique de l'Ouest. Editions IRD. Publication scientifiques de Museum. MRAC, 2004.

Poumogne, V. (1998). Pisciculture en Milieu Tropical Africain. Comment produire du poisson à coût modéré. Presse universitaire d'Afrique, Yaoundé.

Sagna, M. B., Diallo, A., Sarr, P. S., Ndiaye, O., Goffner, D., \& Guisse, A. (2013). Biochemical composition and nutritional value of Balanites aegyptiaca (L.) Del fruit pulps from Northern Ferlo in Senegal.

Sargent, J. R., McEvoy, L., Estevez, A., Bell, J. G., Bell, M. V., Henderson, J. R., \& Tocher, D. R. (1999). Lipid nutrition of marine fish during early development: current status and future directions. Aquaculture, 179, 217-229. https://doi.org/10.1016/S0044-8486(99)00191-X

Teugels, G. G. (1986). Révision systématique des espèces africaines du genre Clarias 


\section{Macrothink}

(Poissons, Clariidae). Ann. Mus. R. Afr. Centr., Sci. Zool., 247, 199 p. (Réf 248).

Thomas, J. D. (1966). On the biology of the catfish Clarias senegalensis, in a man-made lake in the Ghanaian savanna, with particular reference to its feeding habits. Journal of Zoology, London, 148, 476-514. https://doi.org/10.1111/j.1469-7998.1966.tb02964.x

Webster, C. D., \& Lim, C. (2002). Nutrient requirements and feeding of finfish for aquaculture. CABI Publishing, New York. https://doi.org/10.1079/9780851995199.0000

\section{Copyrights}

Copyright for this article is retained by the author(s), with first publication rights granted to the journal.

This is an open-access article distributed under the terms and conditions of the Creative Commons Attribution license (http://creativecommons.org/licenses/by/4.0/) 